University of Rhode Island

DigitalCommons@URI

Open Access Master's Theses

1992

\title{
*Baby Shoe Tattoo*: A Film Script and Critical Preface
}

Anthony R. Amore Jr.

University of Rhode Island

Follow this and additional works at: https://digitalcommons.uri.edu/theses

\section{Recommended Citation}

Amore, Anthony R. Jr., "*Baby Shoe Tattoo*: A Film Script and Critical Preface" (1992). Open Access

Master's Theses. Paper 1157.

https://digitalcommons.uri.edu/theses/1157

This Thesis is brought to you for free and open access by DigitalCommons@URI. It has been accepted for inclusion in Open Access Master's Theses by an authorized administrator of DigitalCommons@URI. For more information, please contact digitalcommons-group@uri.edu. 
"BABY SHOE TATTOO" : A FILM SCRIPT

AND CRITICAL PREFACE

BY

ANTHONY R. AMORE, JR.

A THESIS SUBMITTED IN PARTIAL FULFILLMENT OF THE REQUIREMENTS FOR THE DEGREE OF

MASTERS OF ARTS

IN

ENGLISH 
MASTER OF ARTS THESIS

OF

ANTHONY R. AMORE, JR.

APPROVED : Thesis committee

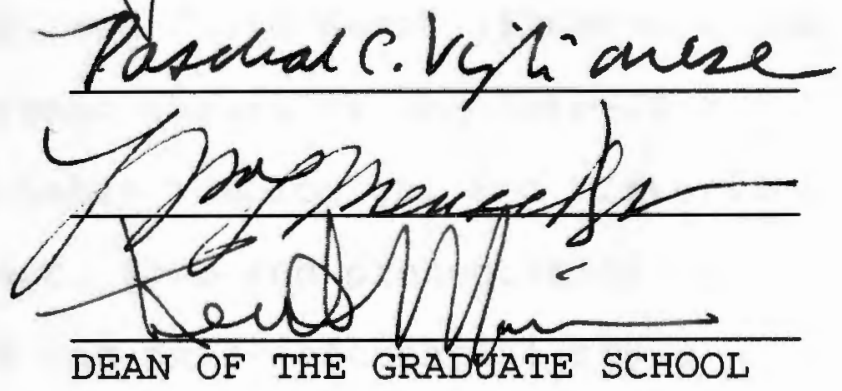




\section{ABSTRACT}

"baby shoe tattoo: A FILM SCRIPT, is the result of inevitable struggles and conflicts between literary theory and production of what becomes known as literature. Postmodernity would have us believe that aesthetic production in our current historical moment centers around disruption and destruction of overarching systems of thought.

Postmoderns, in many respects believe themselves above exploitation of such metanarrative concepts as history and ideology. While works by writers such as Donald Barthelme, Ishmael Reed, Kathy Acker and filmmakers such as David Lynch, the Cohen brothers, and David Mamet illustrate the fragmentary and schizophrenic nature of the late-20th century individual, undeniable ideological and historic links exist between subject, form and presentation.

This study confronts the self-referential style indulged in by many late-20th century artists, and calls into question consequent critical incomprehensibilty as well as dealing with notions of writing/art as "craft". "baby shoe tattoo" attempts redistribution of thought and emotion into a reflective, rather than reflexive, construct. Utilizing film offers greater flexibility in crafting an image through planned and staged production, and this filmscript operates out of historic, cultural and critical modes of experience which shape and mould narrative content and form. 
We are all bound by history, memory and time. ultimately, this study is nothing more than an attempt to interpret effects of time upon relationships, memory and perception.

In researching and writing this filmscript critical sources pertaining to film studies, theorhetical texts authored by specific directors, and filmscripts were utilized. The final bibliography reflects this balance between critical sources and aesthetic constructs.
A.R.A $12 / 92$ 


\section{Acknowledgments}

I would like to thank the following people, without whom this project, and its completion, would not have been possible:

Dr. John Leo for his expertise and insight into media presentation and preparation; as well as his time, energy, and support.

Dr. William Mensel for his conversations which clarified, calmed and instructed my thinking, and also maintained my sanity. I also thank his son, Christopher Mensel, for helping organize and refine my vision.

Drs. Remo Trivelli and Pat Viglionese both of whom expressed willingness, enthusiasm, and great flexibility for a student they only just met.

And most of all, I thank Christina for her love, endurance and honest suppourt; and my family for the same--without all them I lie stranded. 
The corrupt separation of one art from another...the firmly established walls between what I consider to be related or identical manifestations, the synthetic relationships...gave me no peace.

KADINSKY, Germany 1910

...it is the profound ideological meaning of subject and content that is, and always will be, the true basis of aesthetics and that will ensure our mastery of new techniques.

S. M. EISENSTEIN

The cinema is an invention without a future.

LOUIS LUMIERE 


\section{Preface: post/script}

This study's working thesis considers visual practices, in this case filmmaking, as a form of writing. To this end, and to better understand the interplay of language and imagery, or visoverbal relations, I have constructed a filmscript, entitled "baby shoe tattoo", with the hope of gaining access into visual and linguistic modes of signification relative to cinematic production, of detailing the architectural materialism of filmscripts, and considering screenplay as protovisual.

As a filmscript, "baby shoe tattoo" self-consciously represents interplay between dual modes of signification-verbal/linguistic understanding, and visual perception-which in conjunction create what french filmmaker Alain Resnais terms "the image made in seeing" (Monaco, 1979, 2). "baby shoe tattoo" becomes 'metacritical' discourse in the sense that it problematizes itself as protovisual nexus of the verbal and a proposed future "seeing" which redefines and questions institutionalized separations of texts and pictures as distinct mode of representation and signification.

Cinematic representation is a ciphered postcard, a visoverbal scheme possessing simultaneous attributes of both 
visual and verbal expression. Filmmaking follows a dialectic process of architectural materialism through which material film imagery conflict, contrast, and/or connect with (con)textual conception of those images. Cinema speaks an historic language, an "ecriture" or mode of writing whose cultural and critical significance is measurable through distances between points of creation and moments of interpretation (Barthes, 15).

Since post-structuralist discourse does not evaluate language in terms of mere (pure) speech or mere (pure) writing, cinema must work to produce critiques which question traditional notions of mere (pure) images, that is those images considered non-ideological or non-political in nature. Examining dialectic oppositions between known/unknown objects as well as spoken/unspoken languages in both script and on screen might provoke critique and expansion of accepted boundaries which partition language and visual imagery.

During the 1960s, cinematic poets of the French "nouvelle vague" (New Wave) moved. towards and "antiimagistic cinema" which sought "to replace ambiguous connotations of the image with certainties... of the text" (Coates, 6). Their assumption of textual "certainties" rests with the previously privileged notion of textuality and meaning as inherently fixed and bound due to the perceived permanence of written text.

This conception of the text by nouvelle vague 
filmmakers contrasts not only with postmodernity's attitude towards textuality--as imbalanced, fluctuating and whose meaning is highly uncertain with definitive theory of 'text' existing in contemporary terms--but also with films they produced. In practice, elimination of ambiguous connotations within film imagery means trusting the text, and New Wave filmmakers rely on 'concrete' language as remedy for their distrust over uncertain interpretation of images.

cinematically they constructed forms, seamless fusions of sight and sound; a visoverbal architecture which subverts accepted notions of cinema as visual storytelling and moves film to the level of discourse. Disruption of imagery in such films as Truffaut's "The Last Metro" or "Les Quatre Cents Coups" (400 Blows) and Godard's "2 ou 3 choses" or "A bout de souffle" (Breathless), the New Wave establishes literate approaches to film narrative aligning cinema more closely with written narrative forms such as the novel or essay

New Wave filmmakers like Truffaut, Rivette, Resnais, Franju and Godard imbue their images with language assembling film narratives of subjective history and cultural sight. In the late 20 th century film production within the American Hollywood studio system virtually isolates filmscripts as a commodity distinct from visualised results of film production. Writing is less valuable to Hollywood than its more marketable counterpart, film and in more recent years novelizations of films. Particularly 
disrespectful is consideration by a major Hollywood studio to re-novelize "Last of the Mohicans" from Michael Mann's film released this past fall which loosely bases itself on James Cooper's novel.

European filmmakers and filmwriters, more so than American film workers, establish and maintain relationships between screen and the "play" dancing across it through unification of language and image, a union resulting from dialectic between intellectual abstraction and physical movement. Examples abound. A desire to move literal written images from page to cinematic frame motivates Truffaut to kick and jostle his camera in "Jules et Jim"; finds Resnais collaborating with novelists Robbe-Grillet to simulate memory in "L'Annee Derniere a Marienbad", and Marguerite Duras to geographically represent schizophrenia of love in "Hiroshima mon amour"; prompts consideration of Godard as a "theoretical and semiological politician" following films like "Les Carabibiers" (Monaco, 1976, 132-35).

"baby shoe tattoo" attempts such linguistic disruption through visual means. Characters must engage in dialogue which to some degree dictates imagery to the camera for transcription; a writing camera, Alexandre Astruc's "camerastylo". Cinema devises a language which becomes the basis and mode of artistic expression, a translation of written forms into the physical realities of immediate happenings into film record.

Dialectic between physical proximity/material distance 
(how images follow words) and conceptual proximity/critical distance (why images follow words) functions according to political, economic and aesthetic agendas of the filmmaker and the culmination of these tensions becomes a film's architectural materialism. Tension between written screenplays and material film image allows layers of representation to co-exist visually. Juxtaposition and collision of objects, mise-en-scene or material imagery isolates and divests these layers "from that cluster of associations which prevents us from seeing them in themselves" (Durgnat, 19). Each cell of film within the oxymoronic construction of a "motion picture" is an isolated moment, and successive moments suture a film together only to be displaced by other successive narratives within a unified cinematic structure, a structure which has as its basis the solitary frame.

Through repetition and recurrence of images and speech within frames directors create and distort meanings, operate along ideological fronts, and transform knowledge according historical, ideological and cultural texts. Film becomes a postscript, a visual note or reminder of other information than that which presents itself in the body of text. Filmscripts offer the language of visual expectation potential existence through massmedia presentation.

"baby shoe tattoo" represents such a post/script; a note begging realisation. Post/script in this instance becomes event, a stage of material construction where 
filmscript represents a link in the visual helix of film structure and a necessary counterpart to developing knowledge of film imagery as an "ecriture", or mode of writing. The post/script image materially develops itself, within and without its textuality, as film form.

within "baby shoe tattoo" traces of blood, broken coffee cups, unwanted bouquets, urgent mail conspire and frame characters in unshakable cloaks of their history. "baby shoe tattoo" intervenes in the dominant symbolic order of visoverbal signification and offers an alternate mode of signification; diversified ways of seeing and knowing. Moreover, this screenplay questions schizophrenic metanarrative structures which center around psycho-sexual roles and bury "baby shoe"'s characters under "a rubble of distinct and unrelated signifiers"; rubble which--if interpreted and shaped, and understood--fractures unified notions of time, cultural position of the subject, and narrative structures (Harvey, 53).

"baby shoe"'s opening sequence signifies the failure of patriarchal culture to effectively communicate social and aesthetic concepts. In this view, the opening images reject dominant linguistic and visual orders of signification within established narrative discourses. Susan commits suicide in her bathtub, and hands of men lacking sensitivity remove her dead (speechless?) body. She renders herself permanently silent, a condition her death merely reflects rather than embodies; Susan's marital relationship left her 
wounded and bleeding long before razor blades.

Susan's husband Lowell smokes quietly attempting to disengage himself from her act, a behavior he practices repeatedly. Police question him; what is the cause of this? Lowell outwardly believes his wife's miscarriage pushed her over the edge, until he finds a business card and a baby shoe in the toilet. The inability to speak or hear, to translate 'other' languages as well as one's own, isolates Lowell and Susan in childless silence and indifference. It is a silence he refuses to communicate, and an indifference she is consumed by.

"baby shoe tattoo"'s conflict manifests within its structure. Fragmented time makes past and present moments of subjective history psychologically inaccessible. Visual fragmentation of time represents character confusion over slippage among and between variable subjective 'selves': is Lowell a sanitation worker, unmotivated intellectual, or bereaved father repressing guilt and loss; can Susan fit back into her role as artist, as aesthetic creator when she could not create biologically; is Amanda wholly dilettante destined to remain a compilation of everything she halfheartedly attempts, or can these separations represent unified self rather than impetuous post-adolescence.

Memory and time operate in cyclical fragments rather than accepted linear patterns and progressions of daily external clock time, this circle results from violent disunity of each character's internal memory gauges. 
Narrative action occurs within the single locale of Amanda's kitchen during particular moments following Susan's suicide, and this deceptively simple structure shifts violently around recollections of the living regarding the dead.

For the most part, nothing happens in the present moment of the kitchen--Martin, Amanda's father, breaks a plate, Amanda decides to have an abortion, and Lowell drinks coffee, pieces the puzzle of Susan's death together, and gets a tattoo. These small disturbed actions attempt to rectify failures of speech and ignorance of emotional language patterns--Amanda, Lowell and Susan isolate themselves from persons across the table and persons inside. Visually and dramatically, "baby shoe tattoo" represents an attempt to give the unspoken (or more to the point, unheard) voices of Susan, Amanda and Lowell forum through which psychic wounds might be explored within the context of love, birth and death.

As with Resnais and Duras' "Hiroshima mon amour", less concern exists over narratives of time and place than with the effects time and place have upon certain conditional relationships--in "HIroshima"'s case, a love story between a Japanese architect and a French actress in the reconstructed Hiroshima of the late-1950s and early-1960s; in terms of "baby shoe", a literal death of an ambivalent marriage is viewed askew from a mistress' kitchen.

Global conditions effect local circumstance. The "He" and "She" Resnais and writer Marguerite Duras represent must 
coalesce the subjective hell each inhabits with the public paradise they display to one another, and the characters of "baby shoe tattoo" also take part in a similar drama within a differential historic context. Resnais' characters face a crisis of 'self'--"She" must come to terms with her 'crime' of loving a Nazi soldier during the German Occupation of France, and "He" must deal with postwar Japanese denationalization and his own quasi-simulation of Western culture.

Susan faces the institutional, global view expressed by her therapist 'truths' with a combination of confusion and acceptance. Her basic instinct is negated by both Freudian/Self-help psycho-babble on an intellectual level, and her husband on an emotional one. Susan's decision to choose death is the only true commitment made in the filmscript. Actions within the script defend free choice, but simultaneously illustrates the need for personal responsibility and obligations to the other. Failure to name and identify otherness is one aspect of "baby shoe tattoo"s crisis. Amanda and Lowell rarely call each other by name, rarely converse face to face, and engage in an emotional chess match leaving each of them uncertain and off balance, just as the "She" and "He" of "Hiroshima" exist depersonalized and linguistically homeless as unnamed pronouns.

This script attempts to codify and simulate a fractured sensibility, and to visually portray disunity through 
redistribution of objects within their accepted context. The text attempts to solidify dissolved relationships among and between images. Random images within a previously established structure of disunity hints things are not quite as they seem. Perception of the woman sitting in the park rocking a baby carriage seems comforting, maternal, warmly feminine. Purposely the scene connects this maternal image with Susan: the woman in the park has blond hair, Susan has blond hair; Susan bled to death, drops of blood cover this woman's hand and the carriage handle; this woman sits in an isolated park with her child, Susan and her stillborn exist in isolation from everyone. The tone of this image--stark, isolated, dream-like and lyrical--hints at it being psychological, surreal, imaginary.

And, it is: the vision belongs to Lowell. This park sequence is the key to Lowell's indifference and quilt, but not over the loss of his wife and child. Obviously these profoundly influence his actions, yet Lowell's guilt originates with his inability to feel Susan's misscarriage. He cannot identify with physical loss and an immeasurable pain only women know. Lowell's lack of understanding reduces Susan's pain into a reproductive issue easily solved by attempting another child.

The failure of dominant and oppressive symbolic orders (namely Lowell's perceptions and behavior) to enable personal/local communication causes Susan's consideration of suicide as a valid option since mere alteration of 
representation is no answer if there is nothing to represent. Susan cannot paint; her internal divisions remain unexpressable in symbolic terms. Suicide becomes confession or acknowledgement of value and worth. Lowell's behavior objectifies Susan, devaluing her contributions to a union, and in capital societies objects of no value also hold no use. Perceiving such, she removes herself offering confession of Lowell's egotistic sin which manifests itself physically as a baby shoe. Baby shoes represent absence, loss, foundation, and hope. Decision over what must be done with the baby shoe controls any potential resolution.

"baby shoe"'s characters rely upon internal violence and mutilation as resolutions to conflicts and alienation in this "antagonistic, voracious world of otherness" (Harvey, 49). This script address alienation through aesthetic means by "realisation" of itself as a process of alienation, thereby becoming alien in its visual forms. A reader once described "baby shoe" as a possible "anti-film, "or "nonaudience piece." Sight becomes unreliable and language deteriorates into cliche and posture; for the viewer/reader nothing reliable remains, no image, no word.

If postmodernism assumes that overarching metanarratives are flawed by their inherent ideological and historical absences, then our cultural designs and aesthetic ideologies will reflect disruptive and unreliable discursive practices in the sense that meaning no longer remains fixed within a solitary code (Lyotard, xxiii-xxv). Disruptive 
images and languages in filmscripts subvert definitive interpretation of film discourse, and open stages for engaging accepted roles of film and writing. Cinema typifies both subjective sight and language moving critically into a position that allows moving portraits confrontation vis-avis cultural conceptions of which "play" belongs on "screen" .

Recall Euripidies writing in exile, weary and isolated in his vision. All this amounts to nothing without the courage to break moulds. Bergman writes that our "weighty sculpture represents mankind, the gods and the world in merciless and meaningless movement beneath an empty sky" (Bergman, 256).

A. R. Amore, December 1992 
SOUND CUE

Torture by The Cure

EXTREME CLOSE UP

SKETCH PAD

White screen is the face of a sketch pad. A charcoal pencil begins drawing what will become recognizable as a baby shoe.

ROLL TITLE

ROLL CREDITS

Title and credits roll over white sketch paper.

When credits end, and sketch is finished, page is ripped from pad. Motion and sound synced with CUT TO STUDIO

CUT TO

INT LOWELL'S STUDIO LOWELL NIGHT

LOWELL, twenty-nine, sits on the floor smoking a cigarette slowly. He wears a leather jacket, jeans and his shirt is untucked. In the background, the low voices of men can be heard, and the metallic clattering sound of wheels on tile floor. LOWELL places the cigarette in an ashtray and eats some chinese food from a white paper carton.

Camera TRACKS BACK from Lowell. When he is in full view, the camera BEGINS MOVING TO RIGHT. Elements of Lowell's daily life clutter the studio area over which the camera passes.

\section{INT STUDIO BATHROOM DETECTIVES NIGHT}

Men WORK IN BATHROOM at getting Lowell's dead wife, Susan from the tub. When they lift her, one bleeding arm flops past the body bag on the gurney. The bathroom tile is stained with blood and bloody footprints. The detectives have placed a plastic sheet outside the door on which to wipe their feet. 


\section{WORKER 1}

(Iifting body) Ok. Count of three. One, two, three... (They lift, arm flops out).

WORKER 2 flips the arm back into the body bag.

DETECTIVE 1 places an unlit cigarette into his mouth running the filter over his bottom lip. DETECTIVE 1 plays with cigarette, watches WORKERS wheel body out. CORONER pushes through door.

\section{INT STUDIO LOWELL NIGHT}

CAMERA LOOKS DOWN at LOWELL smoking. DETECTIVES MOVE INTO FRAME, only their legs on either side of Lowell are visible. He lifts the carton of chinese food up to the detectives, offering some to them. They decline.

No thanks .

\section{DETECTIVE 1}

\section{DETECTIVE 2}

We know this is difficult, but we need you to come to the station and fill out a report. Procedures, otherwise we wouldn't ask.

\section{DETECTIVE 1}

Is there anything you can tell us, anything at all. Was her behavior different; odd?

\section{DETECTIVE 2}

Was there a note? Some leave notes.

\section{DETECTIVE 1}

We've called ahead. Someone from Social Services will be there to meet with you. A psychiatrist.

\section{DETECTIVE 2}

Is there anyone else you'd like us to notify. A relative? Friend?

\section{DETECTIVE 1}

We'd like to make this as painless as possible.

Would you please come with us.

\section{DETECTIVE 2}

DETECTIVE 1

We need you to get up, please. 
LOWELL stands. Camera follows him up. He nods. They turn to walk out. LOWELL stops, turns and picks up cartons of

chinese food from the floor. LOWELI hands one carton to each Detective, then walks PAST DETECTIVES AND CAMERA. They stand, bewildered. DETECTIVE 2 opens carton, bites spring roll. DETECTIVE 1 takes it from DETECTIVE 2 and they move after Lowell.

EXT. CAR LOWELL NIGHT

LOWELI sits in the back seat of the unmarked police car. Lights shine off parked cars and street through the back window. He stares blankly.

DETECTIVE 1

(vo) You went for chinese food?

LOWELL

(vo) Yes, but the order wasn't ready.

(vo) Not ready?

DETECTIVE 2

LOWELL

(vo) No one called...to place order.

(vo) No one called.

DETECTIVE 1

LOWELL

(vo) Yes, that's right, so, I ordered. It took some time. I can never decide with chinese food.

(vo) You waited.

\section{DETECTIVE 1}

LOWELL

(vo) Waited and had a coffee.

DETECTIVE 2

(vo) You came home and found her.

(vo) In the tub.

\section{LOWELL}

PSYCHOLOGIST

(vo) Had she seemed depressed recently?

(vo) Very. Susan wasn't herself after the miscarriage. 
EXT. STREET OUTSIDE POLICE STATION LOWELL NIGHT

\section{LOWELL}

(vo cont.) She wasn't anybody.

LOWELL stands outside the brightly lit Police station. In his hand is a sealed manila folder in a zip-lock plastic bag. He looks left and right. Cars pass. The sun rises and Lowell walks in one direction out of frame, then crosses back over through frame in opposite direction.

INSERT CLOSE SHOT "WALK" SIGN CHANGES TO "DO NOT WALK" Frame contains pedestrian signal flipping green to red.

EXT STREET CORNER LOWELL

Lowell crosses street. Coming towards him is a woman pushing a baby stroller with another small child holding her hand. Sound sucks itself out like a flame in a vacuum. CAMERA ZOOMS IN to capture LOWELL'S face as he turns to watch the mother and her children walk past.

\section{EXT PARK BENCH WOMAN WITH BABY CARRIAGE}

LONG SHOT of a woman sitting on bench rocking a baby carriage, the springs squeak. Long shot of a lone bench in the middle of a park, or field. The sky is sunny and filling spring trees gently shade their surrounding. It is a natural and comforting image of motherhood, but it appears briefly across the screen for not more than three seconds. The sound of a lullaby melds into a woman's scream.

\section{INT STUDIO SUSAN, LOWELL NIGHT}

SUSAN'S head hangs over the edge of the bed. LOWELL rolls off her, he is barely visible in shot until he moves over to kiss. Lowell has just orgasmed, susan appears unmoved, bored even--feigning contentment a constant part of her sexual strategy. 
LOWELL climbs off the bed and the CAMERA FOLLOWS his walk through the barely lit studio to the bathroom. The light clicks on throwing an illuminating cone across the floor. Running water is heard, and LOWELL HUMS the same nondescript lullaby tune associated with the 'woman in park' image.

\section{INT STUDIO MED SHOT SUSAN IN BED}

SUSAN lay on her side drifting away in her mind. She runs a hand across her stomach drawing the sheet taut. CAMERA FOLLOWS her HAND MOVEMENTS and it becomes obvious Susan is pregnant. Her hand clutches sheet, and her breathing becomes labored. SUSAN screams and twists with pain.

Lowell! Lowell!

SUSAN

(in extreme pain)

Susan falls from the bed.

INSERT CLOSE SHOT NIGHT TABLE

Trying to get up, Susan reaches up. Her hand falls away knocking over a water glass from the night table. The lamp, which is on, goes with it as well.

The lamp falls to the floor and the bulb breaks, the telephone lands with the receiver off the hook. Susan's half of the room sinks into darkness. She writhes on the floor tangled by a shadow wrapped sheet.

\section{OPERATOR}

( $v O$ )

If you'd like to make a call, pleas hang up and dial again. If you need assistance, stay on the line. If you'd like to make a call please hang up...

(os) Susan?

LOWELL

They move in connected silhouette separated only by the sheet Susan is wrapped in.

(cont) Jesus. Wait wait. Omigod, Sue. Phone. 
She grabs on to him, pleading desperately.

LOWELL

(cont) Phone. Call an ambulance. Hold on. Jesus Christ.

Susan gasps and groans holding her stomach. Lowell makes phone call and rushes back to Susan. He holds her there on the floor. She begins crying and holds tightly to him. Lowell strokes her forehead trying to comfort her. Somewhere in the street come a siren, LOWELL looks up for it, but it is not their siren.

EXT STREET CLOSE SHOT FRONT END OF CAR

Car screeches into frame

EXT STREET LOWELL

Lowell turns head to look at car. Quick reaction shot capturing LOWELL'S physical disconnection and absent minded meandering.

\section{DRIVER}

Get out of the road you fucking moron.

Car drives around Lowell, he does not move. Out of depression and guilt, Lowell's eyes involuntarily draw themselves to morbid urban visions. The montage should reflect an emotional connection between Lowell's internal turmoil, and his external surroundings. Emotive connections do not lie inherently in the images but in the totality of connection and juxtaposition of sight, sound, and context.

\section{SOUND CUE}

She's Lost Control, Joy Division (4:45)

Music begins with overlapping the DRIVER's final word:

moron. 
EXT STREET LOWELL WALKING

LOWELL touches his tired eyes, and holds tightly to the impersonal envelopes containing Susan's personal effects.

EXT STREET ADULT BOOKSTORE MEN EXITING

Two well dressed men leave the adult bookstore smiling and joking. Each carries a brown bag.

EXT STREET HOMELESS WOMAN

A woman sits on the doorstep of a closed shop folding an oragami swan using a torn page from a magazine.

EXT STREET EMPTY SHOPPING CART ON STREET CORNER

A shopping cart sits empty and unattended on a street corner framed by brick, covered in shadow.

EXT STREET LOWELL WALKING

Lowell hold items to his chest, walks with arms folded, exhibiting his distress, he looks on things with defensive paranoid eyes.

EXT STREET

PORNO THEATER MARQUIS

Some recent release promising immediate gratification pouts across a small placard.

QUICK PAN EXT STREET PEEP SHOW SIGN

Peep shows advertised at a low rate, a pornographic bargain.

EXT STREET POSTER COVERED TELEPHONE POLE

Telephone covered with unheeded announcements plastered atop one another.

INT STUDIO LOWELL NIGHT

The studio is dimly lit, and while Lowell enters and walks a light connected to a timer clicks itself on. This should be abrupt, but it does not startle him. LOWELL WALKS to the 
bathroom, CAMERA TRACKS him.

\section{LOWELL}

clean.

LOWELL WALKS from bathroom. CAMERA FOLLOWS him over towards the spot he sat in while police removed Susan's body.

INSERT CLOSE UP PACKET OF CIGARETTES

LOWELL picks up packet and lighter.

LOWELL lights a cigarette, inhales and exhales slowly. Reaches down and takes eggroll from carton on window sill, takes bite and chews slowly.

FADE OUT

\section{FADE IN}

CLOSE UP TV SCREEN MARX BROS MOVIE

On the screen, a Marx Brothers film. Harpo is doing something insane, yet totally appropriate. Susan and Lowell engage in phantom dialogue, a past moment appearing within the now.

$$
\begin{aligned}
& \text { (vo) He's an idiot. SUSAN } \\
& \text { LOWELL }
\end{aligned}
$$

(vo) They're all idiots; they're the Marx Brothers. You're suppose to laugh at them.

\section{SUSAN}

(vo) No one can carry stuff like that in his pockets.

\section{LOWELL}

(vo) The point is they're supposed to be idiots and that's what makes them funny.

(vo) Oh. I guess I don't understand funny, then. 


\section{INT STUDIO LOWELL NIGHT}

Lowell sits alone on the couch drinking coffee. The dim light from the television plays off his features casting them in a mask. He gets off couch and walks to the bathroom. CAMERA FOLLOWS SLOWLY.

LOWELL stands in front of toilet, he puts the cigarette in his mouth and lifts the toilet seat. He unzips pants then looks into toilet bowl.

INSERT CLOSE SHOT BABY SHOE \& BUSINESS CARD IN TOILET

Sunk at the bottom of the toilet is a white baby shoe, a business card floats in the water above it. On the rim, hidden under the lid are two bloody fingerprints.

INT BATHROOM LOWELL

LOWELL sits on the floor. He reaches into the toilet retrieving the baby shoe. It dangles by the laces before him.

INT STUDIO SUSAN

SUSAN holds baby shoe by the laces as does Lowell.

\section{INT BATHROOM LOWELL}

LOWELL takes cigarette from his mouth and exhales smoke, he leans elbow on the toilet rim propping up his head with it. He twirls the baby shoe before him as if it holds some secret.

INT STUDIO SUSAN

SUSAN twirls the baby shoe.

\section{AMANDA}

(vo) Took my first steps in these...

Dialogue spoken in ethereal voice over, peripherally as if it were the celluloid recollection of a memory.

INSERT CLOSE SHOT BUSINESS CARD

Card remains floating in toilet bowl. 
LOWELL places cigarette in mouth and reaches in with free hand retrieving card. Looks at it, but says nothing. He sits there smoking.

\section{INSERT CLOSE SHOT BUSINESS CARD}

The name of a florist shop is printed across the card's face.

LOWELL shifts the card into the hand with the baby shoe, takes a final drag off the cigarette and tosses it into the toilet. He waits for a second, then reaches up and flushes. He places elbow on the rim, again leaning his head against his hand. Lowell looks at the shoe and business card that together share his hand. Shaking his head he rubs his chin pensively.

SOUND CUE

WATER RUNNING IN TOILET

INSERT CLOSE SHOT FLORIST BUSINESS CARD

AMANDA

(os) Can I help you with something?

INT FLOWER SHOP AMANDA， LOWELL

Card lays on the counter.

Lowell browses in refrigerated flower case. AMANDA, in her late twenties and casually dressed, works behind the counter.

LOWELL

I need something sympathetic that isn't depressing.

Sick friend?

AMANDA

LOWELL

No, my um wife had an accident. I want to cheer her up.

AMANDA

I could put together a bouquet, something simple. 
sure, fine.

\section{LOWELL}

One second, ok.

\section{AMANDA}

Amanda moves into the greenhouse area connected to the shop but divided by window where MARTIN, late 60's, Amanda's father works. CAMERA FOLLOWS AMANDA'S MOVEMENTS.

PAN TO INT GREENHOUSE AMANDA, MARTIN

AMANDA speaks to MARTIN, but nothing can be heard. Martin, nods and looks at Lowell.

\section{INT FLORIST SHOP LOWELL}

LOWELL looks away, turns and paces the shop's floor.

AMANDA

My father'll arrange something. Seems like the one thing he hasn't forgotten is what to do with flowers. My name's Amanda.

Hi. I'm Lowell.

\section{LOWELL}

\section{AMANDA}

I run the place.

(hands him business card)

Here, that's me. In case you ever, well need flowers or something. I mean, of course if you called it would be for flowers right, that's kind of stupid of me, right.

Yea, right, thanks.

LOWELL

AMANDA

How long you been married?

\section{LOWELL}

Three years... in July.

AMANDA

Three years. Um, so what do you do?

Hauling. I haul things. 


\section{Like what?}

\section{AMANDA}

Trash, garbage. Things.

\section{LOWELL}

\section{AMANDA}

Interesting. What's the difference between trash and garbage?

I don't know.

\section{LOWELL}

I don't know.

Martin walks in with flowers.

AMANDA

(rings in amount) Here we go. Nice and cheerful. That comes to $\$ 5.45$ with tax.

Lowell hands her money. She hands back the change.

Thanks.

\section{LOWELL}

\section{AMANDA}

Hope your wife feels better.

\section{LOWELL}

Thanks, sooner or later she will.

Lowell exits shop, bell on door rings.

AMANDA

(calls after him)

Don't forget who to call, if you need flowers.

\section{INT STUDIO BATHROOM LOWELL}

Lowell looks at the shoe and card, pondering. He gets up and walks out of frame.

\section{INT STUDIO LOWELL}

Lowell lights a cigarette and falls into a chair facing the window. He smokes pensively, and holds the shoe in front of his face. 


\section{INT STUDIO SUSAN}

SUSAN holds baby shoes out before her face.

Dialogue speed is slowed slightly blurring the tone.

First steps...

$$
\text { SUSAN }
$$

INT STUDIO SUSAN, LOWELL MORNING

SUSAN places baby things into box, pausing she takes a cigarette from ashtray, smokes it. LOWELL, in deep focus behind Susan, sits in a chair reading a novel by Yukio Mishima. He is dressed for work in coveralls with the name 'Bob' sew on. They drink coffee.

\section{SUSAN}

I'm told painting might be a good idea.

By whom?

LOWELL

Liz, my therapist.

$$
\text { SUSAN }
$$

\section{LOWELL}

Painting what?

\section{SUSAN}

Nothing specific. It's a gestalt thing, I guess.

\section{LOWELL}

Oh. Well she's the professional.

\section{SUSAN}

It's tough. I can't seem to start. That can't be very therapeutic, can it? Not starting, I mean.

I suppose not, no.

\section{LOWELL}

\section{SUSAN}

Why is it everybody thinks things are so goddamn easy, like saying, "Just paint, It'll make you feel

better". If it were just a matter of doing it I'd have never given it up and I'd be showing some place in the east Village selling stuff I just painted.

She turns around and looks at Lowell. 
SUSAN

(cont.) I wonder why that is with people who think they know everything?

I don't know.

\section{LOWELL}

SUSAN

She thinks therapy might benefit you.

LOWELL

(sarcastic)

Therapy might benefit me.

SUSAN

We both lost something.

(pause)

Don't you agree?

LOWELL

I suppose. How have you benefited? Has all this therapy uncovered anything beside a need for more intensive therapy?

I'm working on resolutions.

SUSAN

LOWELL

Resolutions. When we can resolve a discussion about having another child without hysterics, and...

I said, I'm working on it.

\section{SUSAN}

\section{LOWELL}

... and when we can resolve our sex life, then

I'll reconsider doing a little resolving through redemptive analysis, ok.

Awkward silence.

SUSAN

Stop being combative and deal with something.

LOWELL

Me deal with something? Look at you, it's taken four months to get you to even think about packing that crap. 
SUSAN

(she lights another cigarette forgetting the one she already has)

Things take time.

\title{
LOWELL
}

(under his breath)

The Grand Canyon took less time.

\author{
SUSAN \\ (Turns facing him)
}

The Grand Canyon isn't finished.

Another book?

(Pauses. Turns from him)

LOWELL

Yes.

SUSAN

What about the ones on the night table?

INSERT BOOKS ON NIGHT STAND

Several books are opened turned upside down, or separated with bookmarks.

\section{LOWELL}

(os) They're not going anywhere. I'll get to them.

SUSAN

(os) Should you be spending the money with me not working, is what I'm asking.

\section{LOWELL}

(os) Should we have bought all that baby stuff without a baby?

Sound of hydraulic brakes hiss out in the street. A horn honks loudly.

\section{LOWELL}

(tosses book down, kisses the top of Susan's head) My ride. See you tonight.

Bye.

SUSAN

LOWELL leaves then returns for the cardboard box. 
LOWELL

You wanted me to take this, right?

\section{SUSAN}

Do we have a use for any of it?

\section{LOWELL}

(pause) I'll put it in the basement... Just in case.

Whatever you want.

$$
\text { SUSAN }
$$

\section{LOWELL}

It'll be in the basement for when you're finally done resolving.

Lowell walks off camera. Sound of door shutting.

SUSAN sits quietly alone for a moment, then violently stamps cigarettes out, knocks ashtray off coffee table onto the floor, picks up coffee mug and hurls it at the wall.

\section{INSERT CLOSE SHOT BROKEN COFFEE MUG}

Broken pieces scatter on floor.

She stands arms folded, hand over face.

\section{EXT STREET LOWELL WALKING}

He walks quickly and turns into flower shop. Bell attached to door rings.

\section{INT FLOWER SHOP LOWELL ENTERS SHOP}

LOWELL comes in hurriedly, confusion on his face, door remains open behind him. A small BELL JINGLES as he enters. AMANDA stands behind counter receipts, order forms, and other shop paper work. She SPEAKS ON PHONE.

\section{AMANDA}

Lilies and forget-me-nots would be appropriate, yes, yes fine. Sometime before five, yes, ok, fine.

Hi Lowell. (hangs up phone)

LOWELL doesn't speak. He holds up baby shoe and business card. He brings hands up to his face still holding the baby 
shoe, and covers his eyes. His shoulders shake and heave. AMANDA STANDS up from behind the counter, she HOLDS HER STOMACH and MOVES TOWARDS LOWELL. THEY EMBRACE a comforting embrace of support and mutual confusion. Amanda is pregnant, but has not yet begun to show.

[From this point on in the film Lowell will not be without the baby shoe, even during flashbacks, and Amanda will repeatedly touch her stomach as if validating herself with the ambivalence she feels for the life existing within her. These two actions shall be left to the discretion of the actors contingent upon the physical limitation of any particular scene.]

LOWELL

(emotional)

In the bathroom, in the toilet.

MY God.

AMANDA

She reaches out with her finger and traces the baby shoe LOWELL

She slit her wrists.

My god.

AMANDA

LOWELL

She found out, put things together before I said anything.

Amanda looks towards greenhouse.

INT GREENHOUSE MARTIN AMANDA'S POV

Martin holds some daffodils. He looks up at the two of them.

INT FLOWER SHOP AMANDA, LOWELL

Her face shows concern, questioning and shock. Lowell looks at her.

INT GREENHOUSE

MARTIN

MARTIN smells daffodils, looks at the floor then in the direction of Amanda and Lowell. Martin turns his back and 
moves out of sight.

INSERT INT STUDIO CLOSE SHOT CANVAS

Whiteness invades the frame.

INT STUDIO SUSAN, CANVAS

Susan sits backwards on chair with her arms resting above the back. She appears deep in thought, and totally

frustrated at the nothingness covering the canvas' hidden possibilities.Attainability of expression's form far from Susan's grasp, further than even she believes. CAMERA PULLS BACK, distancing objects from their place, and then MOVES IN FRAMING SUSAN'S PROFILE, she rests her head on her arms, and hums a gentle lullaby which creeps over everything.

INSERT CLOSE SHOT COFFEE MUG

Lullaby continues. AMANDA'S HAND enters frame and POURS COFFEE into mug. Lowell plays with the baby shoe as he speaks.

INT KITCHEN AMANDA, LOWELL DAY

LOWELL

Something from the lab. She saw it. Information about the procedure.

I know.

AMANDA

LOWELL

We agreed not to use my address until I told her.

AMANDA

(she rubs stomach)

This is my fault.

Why is it your fault?

LOWELL

AMANDA

I asked the clinic to mail some stuff, you told me she knew all about it. I thought she knew all about it.

LOWELL

You what, you did what? Why the hell did you do that? Why didn't you tell me first? 
AMANDA

I felt guilty and, well figured she would want to be involved. You were supposed to have told her, you said you told her.

\section{LOWELL}

Well, I hadn't. Her moods shifted so often I kept putting it off. My God how has this happened.

AMANDA

I'm sorry, I didn't mean for any of this to happen.

LOWELL

Why didn't you let me explain to her about the insemination, maybe this could've been avoided, this whole mess erased. Couldn't you think about someone other than yourself, Jesus Christ.

LOWELL chews his lower lip.

AMANDA

Goddamn it, we never should have...

EXT URBAN COURTYARD LOWELL, AMANDA DAY

Eating his lunch in a brick courtyard, LOWELL tosses crumbs to pigeons and reads from yet another book. AMANDA walks by carrying a cello.

\section{AMANDA}

I thought you looked familiar:

Excuse me?

LOWELL

AMANDA leans on cello.

AMANDA

You haven't been in my shop, for flowers.

Oh, yea, right.

LOWELL

AMANDA

Behaving yourself. Usually you seem to wait till you're in trouble like most men.

LOWELL

How do you know I'm not in trouble all the time. 


\title{
AMANDA
}

Maybe you are. I don't know. What're you reading.

Proust.

\section{LOWELL}

\author{
AMANDA
}

Why?

Because I want to.

LOWELL

AMANDA

Please. The only people who read Proust do it either because they have to, or because they're trying to get lost in the endless tedium of someone else's life.

You believe that?

LOWELL

AMANDA

(sitting) I dated a professor who was a Proust nut. He re-read Remembrances of Things Past constantly, it was pathological, he claimed the purpose was to "illuminate the text". Well I told him once that he spent all that time trying to figure out a book so he could avoid dealing with life; besides any book so complicated isn't worth reading. Anyway, he stopped calling so I must have been right. Seems to me, every reading person hides from something burying their noses in books.

Really.

LOWELL

AMANDA

Really. Are you avoiding something?

LOWELL

Right now, having lunch across the street with the rest of the crew I work with. I can only take so many genitalia jokes.

AMANDA

I see. Is this a three book lunch? (points at other books beside Lowell's lunch bag)

LOWELL

Bad habit I picked up in college. I can't read one book at a time.

AMANDA

So how long before you finish these. 


\section{LOWELL}

Depends. Probably a while. I seem to lose my place and have to start the same book over and over. Pretty strange, huh.

AMANDA

No, not really. I've heard stranger.

\section{LOWELL}

Like what? What's stranger?

\section{AMANDA}

My best friend Deb is strange. She was raped three years ago, and instead of finding the guy and castrating him, like anyone would, she opted for the next best revenge on the male scumbag population.

What's that?

\section{LOWELL}

\section{AMANDA}

Working as an exotic dancer in some strip joint, to hear her tell it, torturing people with what they can't actually have is a worse than a life sentence. She gets these guys so hot they have to jerk off in the men's room, and sometimes they turn on one another right there competeing for her--that I'veseen--to her it's the ultimate revenge. They lose money and control to her. She's in charge and anyone who gets out of line, Deb has the bouncer smash their head.

\section{LOWELL}

Isn't she afraid of getting raped again?

\section{AMANDA}

Nah. She's protected, and sexual empowerment has helped her, at least her therapist seems to think so.

LOWELL

Her therapist thinks the whole thing is a good idea? AMANDA

The woman helped get her the job for chrissake.

That is strange.

\section{LOWELL}

\section{AMANDA}

Told ya. Anyone who thinks they're strange turns out rather normal--they're just afraid to admit it. It's the people who think they're normal that scare the hell out of me. They go into Pizza Hut with semi-automatics and perforate the place. 
(impersonates semi-automatic machine gun)

know what your problem is?

Do tell.

\section{LOWELL}

AMANDA

(nodding)

you can't commit to anything.

LOWELL (slightly defensive)

Really? Is that a fact.

AMANDA

You can't commit to reading a whole book, you can't commit to a consistent vision of yourself or the role you want to play, and you csn't committ to your wife because you buy her so many flowers.

LOWELL

I'm very committed to my wife.

\section{AMANDA}

Interesting that's the only one you picked to dispute. When something's wrong find a cure instead of treating the symptoms. Most people choose the Band-Aid approach because it's simple and obvious, but you can't cure AIDS with a bandage, know what I'm saying.

Band-Aid approach, huh.

\section{LOWELL}

AMANDA

Avoidance and patronizing never works. It's easier but conflicts usually don't just go away all by themselves.

LOWELL

Is all this experience or do you just watch a lot of Oprah?

AMANDA

Two years ago I got divorced.

Sorry.

LOWELL

AMANDA

Don't be, I wasn't married to you. Things fall apart, or more importantly never fit together the way you wished they would. Know how I know all this? 
Crystal ball?

\section{LOWELL}

\section{AMANDA}

(points to his name tag)

you're not wearing your own clothes. Got any kids?

Um, no. No kids.

\section{LOWELL}

\section{AMANDA}

You should have some. My father says children change everything, give life perspective.

\section{LOWELL}

Life isn't exactly like a sneaker commercial. Not everything is as simple as saying, "Let's do it."

\section{AMANDA}

Sure it is. You sound just like my ex. Jesus, who out there is sure about anything like being a parent. Doubt is part of life, but I've always been willing to give up my fears long enough to know what giving birth feels like.

LOWELL

Some things can get complicated though.

AMANDA

Only if we make them that way.

\section{LOWELL}

Look I hardly know you and well, you don't know everything and everything is not simple, especially when you have taken chances and lost. Someone always gets hurt along the way, it's inevitable. Part of life, right.

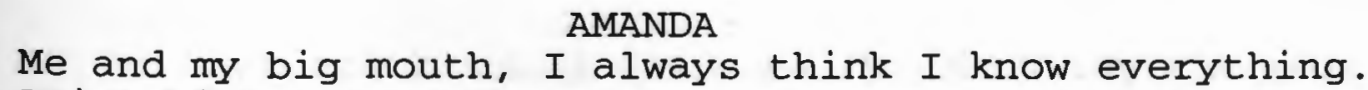
Being bitter does that.

\section{LOWELL}

Well, at least you only lost a grown person who at the very least had the chance to affect your life. Remember that when you get bitter next time.

Sound of truck starting from a cross the street.

MAN

(os) Hey Lowell, c'mon. Back to work, man. 
See ya.

Bye?

AMANDA

Lowell walks off. Amanda sits bewildered at his last remark

INT KITCHEN LOWELL, AMANDA

They sit silently at a kitchen table drinking coffee.

(vo) And are you afraid?

AMANDA

LOWELL

(vo) Isn't everybody? Mostly I'm confused.

Amanda rests a hand across her stomach and toys with mug spinning it in circles.

AMANDA

I wasn't prepared to keep and care for this child, Lowell, you knew that. Shit, I hate to bring this up now, but I feel...

I know.

\section{LOWELL}

AMANDA

Your responsibility was arranging the adoption.

LOWELL

Do you think I planned this. Do you think I wanted to be sitting here having this conversation. Do you think I wanted Susan...

\section{AMANDA}

No, no. I'm not blaming you, really. Handling the pain of giving birth is one thing, the pain of raising a child I can't handle.

Lowell looks up from table.

\section{LOWELL}

Amanda, you're right, I am responsible.

\section{AMANDA}

I'm not prepared to keep this child, I can't keep this child. 
I'm responsible. I know that. I know I'm responsible.

SOUND CUE

This night has opened my eyes, The Smiths. Plays softly in the background.

\section{EXT PARK WOMAN ON BENCH}

Woman sits on bench rocking a baby carriage. Her hand creeps into the carriage and a distant lullaby begins. Movements are slowed, though not in drastically slow motion.

CAMERA PANS WOMAN from head and shoulders, down woman's arm. CAMERA ENDS PAN when it reaches edge of carriages handle. Woman presses down blankets, which are out of sight. She raises her hand from carriage. Before hand is totally visible...

INSERT

EXT PARK

CLOSE UP

CARRIAGE HANDLE

Drops of blood fall on handle.

INT STUDIO SUSAN NIGHT

SUSAN sits up abruptly in bed rattled by nightmarish images. CAMERA PANS TO LOWELL'S SIDE OF THE. BED which is empty.

INT STUDIO LOWELL NIGHT

SHOT FROM OVER-SUSAN'S SHOULDER. LOWELL sits smoking a cigarette. Light from a street lamp comes through and encircles him.

CUT TO SUSAN IN BED

Susan sits up and looks at Lowell.

CUT TO LOWELL SMOKING

LOWELL stares out the window. His mind blurred, he wonders about equity in a world that un-naturally kills its children. 
CUT TO SUSAN IN BED

SUSAN watches him, she lies on her side facing Lowell

realizing Lowell's pain, confusion and loss materialize in smoke rising from his fingers.

INSERT CLOSE SHOT SMOKE RISING FROM CIGARETTE

(os) Do you dream?
(os) When I sleep.

SUSAN

(os) Do you see her?

(os) Sometimes.

LOWELL

SUSAN

(os) What do you see?

LOWELL

(os) The two of you sitting... in a park.

EXT PARK WOMAN ON BENCH DAY

FAR SHOT of the recurring image of the mother with carriage in park.

INT STUDIO CIGARETTE IN LOWELL'S HAND

CAMERA BEGINS SLOW PAN DOWN from the top of rising smoke TO LOWELL'S HAND.

\section{SUSAN}

\section{LOWELL}

(os) I don't remember actually seeing her. Her being around is more implied.

(os) Implied?

SUSAN 
CAMERA FOLLOWS LOWELL'S HAND. He raises cigarette to lips and his face is caught in profile as he smokes and ponders.

LOWELL

\section{(irritated)}

Things are there, baby things--a carriage, a cry, notes from a lullaby, baby shoes maybe, different things, I don't know, just thing that let you know a baby is around somewhere even if you can't see it. Can we drop this subject?

\section{SUSAN}

(os) We've spent too much time dropping the subject, don't you think?

SUSAN'S HAND ENTERS FRAME RESTING on Lowell's shoulder. He does not touch her hand. SUSAN circles around in front of him.

Hmm. Who knows.

\section{LOWELL}

SUSAN

We used to talk. Didn't we?

\section{LOWELL}

We used to do lots of things. I find it hard to trust both of us right now, ok. We're too sensitive about all this

\section{SUSAN}

(annoyed)

I didn't think it was possible to be too sensitive about losing a baby. You just can't be bothered with me.

\section{LOWELL}

It's not just you, it's everything. Just forget it.

\section{SUSAN}

You make it kind of impossible to forget it. You won't sleep in the same bed with me, you won't talk to me, you pick up extra shifts and overtime at work...

\section{LOWELL}

We need the money, I'm the only one working remember.

\section{SUSAN}

This is not a money issue and you know it. You're avoiding me, avoiding us, avoiding this whole thing. And what about the flowers, like they're supposed to remind me you care? Roses don't replace feelings. Stop trying to placate me for once, and try helping me, helping us, deal with this instead of hoping it'li just 
go away.

LOWELL

That's not what I'm doing. I'm dealing with it my way, the only way I know how.

SUSAN

In other words by not dealing with it, like I said. You've always run, from your family, from me, from yourself. Stop running Lowell.

LOWELL

I don't trust myself, what I think, what I might say...

\section{SUSAN}

And, possibly, what you might feel? Because you can't control it and begin again like with one of your books. Look, if we turn on each other, we lose everything.

LOWELL sits in chair staring down, and always away from Susan.

LOWELL

Haven't we already lost everything? Maybe we deserve to lose everything, I can't seem to rationalize this any other way.

SUSAN

Yes you can, you just don't want to. Self-pity is the easiest trip of all.

LOWELL

I remember thinking how I'd be a different father than my father. It's not that he beat us or anything, it was the opposite--he never paid attention to us. Anyway I remember asking God, back when I believed in God, to make the baby healthy and then, just for a second, I thought, 'Don't make me that kind of a father, or I'd just as soon not have any kids.' Sort of makes you stop and think, doesn't it.

\section{SUSAN}

This really isn't our fault. It's no longer a question of blame.

Maybe. Maybe not.

LOWELL

SUSAN

Self-pity makes everything uglier. Especially yourself. 
SUSAN SITS on floor and looks up at Lowell. LOWELL nods and stares past her out the window. Both of then sit encircled by the street lamps still glow.

LOWELL

Things have gotten ugly, that's for sure. Now I wonder if I was wrong, if I'd be nothing like my father which is why I gave up on school. All that time spent with his books, and his empty theories, and his hollow writing.

\section{SUSAN}

You're not the only one who's scared, here, I mean my parents are no prize either. Everybody's human, no one's perfect. But just because your related to crazy people doesn't mean you'll turn out crazy too.

\section{LOWELL}

You know my father never dedicated a single book to a family member, not one.

\section{SUSAN}

Don't beat up on yourself, and us, because of what you believe are your father's transgressions.

\section{LOWELL}

Let's just forget about this. I'm not in the mood to go any further with this crap. Any minute you'll bring up my inner child or something as equally moronic that your shrink spouts off.

\section{SUSAN}

We might be getting somewhere.

\section{LOWELL}

I'd rather not get anywhere, this isn't helping.

Maybe I need to hear from you.

$$
\text { SUSAN }
$$

LOWELL

No, just, I just cannot get into this anymore. I might say something stupid if we go any further alright.

\section{SUSAN}

Stupid? What could be stupid about how you feel?

LOWELL

Quit badgering, you never can just leave something alone, and let me deal with the rest of what I have to deal with on my own. 
This is a marriage. Neither of us is on our own here.

\section{LOWELL}

Maybe that's part of the problem--this marriage hasn't worked for a while.

\section{SUSAN}

What the hell are you talking about. We've only been together a while.

\section{LOWELL}

I want another child and I want one soon, I want one now.

SUSAN

Like that's a solution. I can't...besides you said...

\section{LOWELL}

Forget what I said. I need to know that I was wrong, about me being my father, about us, I need to know.

\section{SUSAN}

Now, I can't. There's no way...

LOWELL

Then I'll have to rethink this whole thing.

Thing?

$$
\text { SUSAN }
$$

\section{LOWELL}

Thing! Thing! Yes thing, this marriage. Do I have to spell it out $M-A-R-R-\ldots$

SUSAN STANDS and walks half-way towards him. Camera pulls back and follows her; both of them are framed. She stops, shakes her head and sits in the chair where Lowell had been. On the window sill is a packet of cigarettes, Susan takes one and picks up the lighter next to it.

\section{SUSAN}

You sonuvabitch. You tell me what scares the fuck out of you and what next, you turn, fight back because Honesty scares you more than, than anything because then you lose the power of that crutch, that excuse for your behavior. Well, I'm honest enough to admit that we did not cause this. Our baby died, suffocated inside me, we had nothing to do with this.

SUSAN walks around in circles smoking and talking mostly to 
herself.

\section{SUSAN}

(cont) Now, there are you happy. My crutch is gone, snap just like that, so let's just jump right in bed and fuck and make another kid if that's all it takes to get some participation here, to get you motivated enough to help me deal with the fact that my baby, my goddamn daughter died inside me! You know, it just occurred that maybe I'm wrong, maybe you can't support me at all because all this pulling away just shows your inability to see past yourself and grow up. I'm supposed to rise late at night and search for you, stroke your insomniac head, and say, "Oh, poor baby, everything will turn out a-ok." Well, I'm not your mother, I'm your wife and you weren't even there when the doctors pulled her out of me--Where the hell were you! Huh!

I, I, uh, I was in the...

\section{LOWELL}

\section{SUSAN}

I'll tell you where you were. In the waiting room sitting, pacing, biting nails, probably reading a magazine and drinking coffee, while I had my feet in the air and a hand inside me trying to cut the fucking cord wrapped around her neck and nobody there would hold my fucking hand.

I didn't know.

\section{LOWELL}

\section{SUSAN}

You never asked, obviously you were busy obsessing over some inane conversation with a supposedly supreme being and your father's failure to nurture you while I watched our daughter die and there wasn't a fucking thing I could do... I cannot believe that all this time the only person you've thought about was you and how this has affected your life.

LOWELL moves to her, tries touch her shoulder but Susan moves away.

\section{SUSAN}

Get the fuck away from me you bastard, back the fuck off me, I did it without you then, I'll do it without you, now. 
LOWELL

(backing off)

I'm sorry, sue. I had no idea.

INT FLOWER SHOP FLOWERS

several flower arrangements compose frame.

(os) Trouble?

AMANDA

LOWELL

(os) More or less. That obvious?

INT FLOWER SHOP AMANDA, LOWELL DAY

AMANDA

Guilt's a great motivator. What'd you do?

LOWELL

Nothing worth mentioning, but something worth buying flowers for. Could you deliver those too, I'll never get home before lunch is over and, they'll die if I put them in the truck.

AMANDA

I could keep them until after work, if you like.

LOWELL

Really, I'd rather get them delivered before I get home.

AMANDA

You're in deep shit, huh.

More or less.

LOWELL

\section{AMANDA}

Sure, I'll get them to her this afternoon. You want a card, sometimes a card helps right a few wrongs.

LOWELL

Trying to express myself got me in trouble in the first place. Think I'll pass thank you.

On your lunch break. \$19.50. 
LOWELL

Yea, how much again?

(counts money)

AMANDA

$\$ 19.50$. By the way, I'm sorry about the other day.

(she counts change)

No problem.

LOWELL

AMANDA

I was going to take lunch myself, want some company?

LOWELL

No behavioral analysis this time?

Promise.

AMANDA

(points at book under his arm)

So what's for lunch today?

The Blood Oranges.

LOWELL

Blood oranges?

AMANDA

LOWELL

AMANDA

So basically, it's about otherwise intelligent, but overly neurotic people creating problems for themselves.

Basically, I guess.

\section{LOWELL}

AMANDA

Hey dad. Dad! C'mere. Dad! Stop messing with the ferns and come here for a second.

MARTIN

Quit hollering, I'm not deaf yet. Whatta you need.

AMANDA

Can you please deliver these to the address here. My friend Lowell and $I$ are going to lunch. Just lock up, I'll reopen in a half hour or so. 


\section{MARTIN}

(annoyed)

Whatever.

LOWELL AND AMANDA leave store. Bell rings above door rings as it closes. Martin stands watching them walk past the shop window down the sidewalk with a concerned grumpy look on his face.

INSERT CLOSE SHOT TIP OF CIGARETTE BEING LIT

A flame shoots from the lighter over the tip of the cigarette.

CAMERA ZOOMS OUT SLOWLY bringing SUSAN'S HAND into view, she holds the cigarette upright and it moves across the frame to her lips. Daylight creeps into the frame.

\section{INT STUDIO SUSAN IN CHAIR DAY}

It is the morning after and Susan is lost. Looking for direction she moves to the stereo and tries the radio. FM gives her nothing but sugar coated bullshit about loves no one ever knew, and pain no one ever really felt. This bores her.

INSERT CLOSE UP AM/FM BAND SELECTOR CONTROL

She tries AM radio instead, searching for some honesty. What she finds is a woman talk show host discussing why emotionally and physically battered women remain in destructive relationships. At first this appeals to her, until the subject degrades itself by turning into spectacle.

(vo) So you think they like it then?

CALLER 1

(vo) Absolutely, I mean some women find it attractive, macho and all that crap; they like gettin hit that's why they stay.

(vo) You hit your wife?

HOST

CALLER 1

(vo) I ain't married. 
HOST

(vo) No wonder. Good bye. You're on, what's your bitch?

SUSAN walks across the frame.

INSERT CLOSE SHOT FUNCTION SELECTOR CONTROL

SUSAN'S hand flips it to $C D$.

SOUND CUE

Joy Division's No Love Lost begins.

INT STUDIO SUSAN

SUSAN leans against the wall drinking from a coffee mug.

EXT STREET LOWELL

LOWELL TOSSES TRASH into the garbage truck. He stops for a second to consider, or re-consider something, then Lowell resumes tossing trash.

EXT CEMETERY HEADSTONES

Shot of numerous anonymous headstones.

INT HOSPITAL NURSERY BASSINETS

CAMERA MOVES ACROSS the observation window. MOst of the bassinets are childless.

INT STUDIO SUSAN

SUSAN drinks from coffee mug and looks out of the window.

CAMERA PANS AWAY FROM SUSAN, PAN ENDS WITH SUSAN sitting where she was when scene began. MUSIC ENDS, SILENCE BEGINS.

SOUND OF FAINT KNOCKING at door.

There is a knock at the door. SUSAN's eyes are closed. (Is anyone ever where they are supposed to be?)

SUSAN opens her eyes, she is startled. Knocking at door continues, she moves to answer it. Opening the door she 
finds MARTIN, a man in his late 60 's, standing there with a box of long stem roses tied with a bow.

Hello?

SUSAN

MARTIN

I'm sorry.

SUSAN

Sorry? Sorry about what?

MARTIN

About you losing your baby.

What?

SUSAN

MARTIN

Um. Oh, well the card. I read it. I'm sorry.

Card?

\section{SUSAN}

MARTIN

Yes. I read them all the time, but this time, I, uh, forgot it at the shop. Yea. Think I dropped it, don't know where, as I was leaving. I'm sorry. My memory's bad.

(taps side of head)

SUSAN

Fine. Do I have to sign something.

Yea this.

MARTIN

MARTIN hands her clipboard, she signs. Martin moves out door and into hall, but sticks his head back in. Susan has turned away from door and is opening the box of flowers.

\section{MARTIN}

(cont) My wife and I lost a child; the twin to my surviving daughter. After a time you realize nothing is ever really gone. She's gone, your baby, out there some place, and she understands your pain. Grieve, but don't cut yourself off from this world.

MARTIN LEAVES. SUSAN looks up surprised, turns and MOVES OUT dOOr INTO THE HALLWAY. 
SUSAN looks left then right. Martin is gone; the hall is dim and empty. SUSAN REENTERS STUDIO

\section{INSERT CLOSE UP RED ROSE}

Color fills frame. Quiet sound of silverware scraping against plates is heard behind the flowers.

INT STUDIO DINING TABLE SUSAN, LOWELL NIGHT

They sit across from each other. LOWELL reads a different book from the one he read earlier. SUSAN focuses on her plate. They do not engage each others eyes.

Someone sent flowers.

$$
\text { SUSAN }
$$

They're nice.

LOWELL

\section{SUSAN}

I'm going to kill myself. If someone sends anymore heartfelt apologies, or sympathy, I will kill myself.

\section{LOWELL}

That's a bit extreme, don't you think?

\section{SUSAN}

Maybe, maybe not. These flowers came without a card. The delivery man brought them apologized up and down for losing the card. Apparently he read it.

LOWELL is confused. He knows that the roses are from him and can't understand the mix up.

\section{EXT STREET MARTIN DAY}

MARTIN looks at a key ring overloaded with keys. He walks up beside a white van and locates the key to unlock the door when another delivery man pushes past him and climbs into the drivers seat and speeds off. Martin stands there, scratching his head and examining the key. CAMERA PANS TO OPPOSITE SIDE OF STREET where Martin's van is parked.

\section{LOWELL}

( $\mathrm{VO}$ )

Yea they do don't they. 


\section{SUSAN}

(vo)

Yea, like forgetting to tip him. Can you believe that, a waitress forgetting to tip.

INT STUDIO DINING TABLE LOWELL, SUSAN NIGHT

LOWELL

You haven't been a waitress for a while. Besides, who doesn't forget now and again.

Yea. How was work?

SUSAN

LOWELL

Same as every other day--more garbage than the day before.

Maybe they have it?

$$
\text { SUSAN }
$$

LOWELL

What?

$$
\text { SUSAN }
$$

The note. Maybe the flower shop knows who sent them.

\section{LOWELL}

If he said the card is lost, it's probably gone for good. Why obssess over it.

\section{SUSAN}

I'm not obsessing, just curious. Don't you ever get curious.

CAMERA BEGINS SLOW PAN over to bookshelf and SUSAN'S art supplies while they converse.

Not really, no.

LOWELL

SUSAN

What does Rollo May call the un-curious--insensitive.

I don't know.

LOWELL 
Dead. He called them dead.

SUSAN

Lowell

That might have been Burber.

END PAN focused on a half finished painting and a half read book next to it. They go back to eating silently

INT KITCHEN CLOSE SHOT WHISTLING TEA POT

AMANDA'S hand enters frame and removes tea pot from burner.

\section{AMANDA}

(os) This is crazy, isn't it? I'm crazy right, tell me I'm crazy.

DEB

(vo through phone)

Fine your crazy. How the hell did you even get on the topic anyway, I mean there you are eating lunch and you say some thing like--"Artificially inseminate me, please."

\section{INT KITCHEN AMANDA ON PHONE}

AMANDA leans against kitchen counter dipping tea bag up and down in the cup as she talks.

No, no it was more like...

$$
\text { AMANDA }
$$

EXT COURTYARD LOWELL, AMANDA DAY

AMANDA

So, I read in Time Magazine that more single women are opting for artificial insemination as means for conception.

LOWELL looks up from his book.

DEB

(vo) To a total stranger, you just bring this up out of thin air. 
AMANDA

Yea well, I'm more nervous telling you about this than I was asking him.

EXT COURTYARD AMANDA, LOWELL

AMANDA

You don't have to decide now, just think about it. Talk to your wife and let me know.

INT KITCHEN AMANDA SITS ON FLOOR

DEB

(vo) Unbelievable. So what's the verdict?

AMANDA

Well I have an appointment next week just to see if things can take root.

DEB

(vo) Tell your father yet?

INT KITCHEN AMANDA, LOWELL, MARTIN DAY

Amanda touches her pregnant stomach. Everyone sits or stands around the room absorbed in their own thoughts.

AMANDA

(vo)

He has no idea what day it is, how's he going to comprehend this?

AMANDA looks at MARTIN who looks at a sandwich on his plate which he begins eating. LOWELL stands behind him looking at floor playing with the baby shoe. MARTIN methodically eats his sandwich.

CUT TO CLOSE UP PLAY BUTTON ON WALKMAN TAPE PLAYER

SOUND CUE

Bright Mississippi, Thelonius Monk. Music begins after a two second delay when MARTIN presses the PLAY button. 
INT GREENHOUSE MARTIN DAY

MARTIN mists plants.

INT KITCHEN CLOSE SHOT MARTIN EATING SANDWICH

MARTIN holds sandwich over his mouth, it blocks the lower part of his face. Bright Mississippi continues in background.

INT GREENHOUSE MARTIN

MARTIN fluffs up ferns and leaves of plants, hums along with music.

INT KITCHEN CLOSE SHOT SANDWICH

Sandwich is put down on plate and napkin next to it is picked up. CAMERA FOLLOWS NAPKIN to Martin's mouth as he wipes lip.

\section{INT GREENHOUSE MARTIN}

Behind MARTIN, the blurred figure of SUSAN moves across background to the phone. Although we cannot clearly focus upon her and her action, both are obvious. When she turns in the direction of where MARTIN stands working, AMANDA comes into DEEP FOCUS and both of them appear in the frame together. AMANDA storms into the greenhouse and pushes MARTIN.

\section{MARTIN}

Jesus Christ, trying to give me a heart attack.

\section{AMANDA}

What the hell are you trying to pull? You'll ruin everything.

\section{MARTIN}

What the hell are you talking about?

\section{AMANDA}

You delivered flowers to Lowell's wife yesterday, what the hell did you say to her. She just called asking about the note, and who sent them and all this other shit.

I don't remember, but obviously, I just let something 
slip out, you know real innocent like, accidentally.

AMANDA

About what, what did you let slip.

MARTIN

I'm not sure, um, maybe something about losing her baby or something, but I can't be positive.

Dad, jesus.

\section{AMANDA}

MARTIN

It was an accident; I overheard you and what's-his-name the other day, and... it was an accident, I felt bad.

AMANDA

I don't believe in accidents Dad, neither did Freud.

\section{MARTIN}

You talk just like someone who almost finished one of those college classes she signed up for.

AMANDA

You make me nuts.

\section{(groans)}

\section{MARTIN}

You were that way long before I got my hands on you doll.

She hits him with some flowers.

AMANDA

Just watch what you say and who you say it to from now on, ok.

(she rubs her stomach, takes flowers to front)

Yes dear.

\section{MARTIN}

(puts headphones back on)

\section{INT KITCHEN CLOSE SHOT EMPTY PLATE}

MARTIN runs his finger over the plate picking up crumbs camera follows it to his mouth.

INT KITCHEN MARTIN, AMANDA, LOWELL

MARTIN pushes away plate, AMANDA drinks from a glass of water, LOWELL stares out a window biting his thumb nail. 
SOUND OF WOMAN SINGING lullaby begins in background.

CAMERA MOVES IN TOWARDS LOWELL, over and past Amanda and Martin. As the camera moves in closer, the biting sound of him chewing on his thumb nail grows louder. The lullaby is still audible.

\section{CUT TO BLACK SCREEN}

SOUND: The muffled groaning of a struggling woman, thumping, banging against something solid. Vainly the verbal and physical struggle continues but nothing breaks the frames blackness. Then, with A GASP FROM SUSAN'S THROAT, a hand violently reaches outward from deep in the frame towards the camera as if to grab it. The hands and nails are dark, dirty, looking as though SUSAN has been digging in dirt.

LULLABY continues in background.

\section{INT STUDIO SUSAN NIGHT}

SUSAN SITS UP startled by the dream, breathing heavily, she is sweating. LOWELL IS NOT IN BED. She wipes her forehead. After a moment LOWELL WALKS ACROSS the FRAME with a rose in one hand and cigarette in other. SUSAN WATCHES him unsure of her state--dream or consciousness. She moves her lips to speak, decides against it, and lies back in bed pulling the covers over her head.

LULLABY abruptly ends.

\section{INT KITCHEN LOWELL, AMANDA}

LOWELL leans against the wall facing in one direction, AMANDA sits staring in the opposite direction.

\section{SUSAN}

(vo) Last night I was buried alive again.

\section{LIZ}

(vo) Sub-conscious manifestations of self-limitation, I see it all the time. Guilt holds you back.

\section{INT STUDIO SUSAN DAY}

SUSAN sits on couch with phone to her ear, she toys with the cord as she speaks to Liz, her therapist. 
SUSAN

They feel too natural to be called nightmares though.

LIZ

(vo) do you hear what you're doing? Sounds like your blocking something there by saying they feel more or less normal.

\section{SUSAN}

The dream started because of the delivery man.

\section{LIZ}

(vo) Sometimes we falsify catalysts, when events-physical, emotional, or psychological--occur because we want them too, forcing action. It's your psyches way of telling the rest of you to move on. I doubt there was a delivery man at all.

\section{SUSAN}

He brought roses. I'm looking right at them.

\section{LIZ}

(vo) What he brought is less important than what he left, which is an emotional trigger.

\section{SUSAN}

I don't feel triggered. I don't feel anything. That's what I'm trying...

\section{LIZ}

(vo) You're masking again, Susan.

Masking?

\section{SUSAN}

\section{LIZ}

(vo) You're using nightmares as excuses for failing to reach a level of understanding you would have reach through therapy. You took the step trying to help yourself, now take another and let that happen. All barriers are temporary, Susan.

\section{SUSAN}

Not every barrier is temporary like death, or large bodies of water between continents...

\section{LIZ}

(vo) That's avoidance, listen to yourself--try and avoid devaluing the choices that you make. Stand up for those decisions and be positive about them. Remember, every expanse can be travelled over, even oceans, you just have to decide whether or not to travel. 


\section{SUSAN}

Yea, I haven't decided on what decisions I should make. My husband Lowell says this is my fault, I'm responsible for...

\section{LIZ}

(vo) Sometimes we hear what we want to hear, and use false interpretations of what is really unsaid as an excuse to act. Trust only in your self, Susan, and what you have to say.

\section{SUSAN}

I, I do but sometimes Lowell backs me into emotional corners I never knew...

\section{LIZ}

(vo) Displacement is as unhealthy as avoidance...Don't re-appropriate blame back to your husband because he heaps it on you, play the victim remain the victim. Break the pattern and assume responsibility for only what is yours to claim. Look Sue I've got an appointment now. If you want to want to re-schedule, tell the receptionist when I transfer you, ok

Ok, fine.

$$
\text { SUSAN }
$$

\section{LIZ}

(vo) Good. Be positive. Bye.

Phone clicks, receptionist comes on.

\section{RECEPTIONIST}

(vo) Susan would you like to bill the phone session to your credit card or at your next appointment?

Next time.

$$
\text { SUSAN }
$$

Susan hangs up phone, looks disgusted. She is questioning the ability of Jell-o mold analysis to bring her closer to her fears. She drinks some coffee and walks over to the roses.

\section{INT KITCHEN AMANDA, LOWELL}

AMANDA shuffles through some mail, LOWELL watches. She stops at one particular envelope and begins opening it. 
INT STUDIO CLOSE SHOT HANDS OPENING ENVELOPE

SUSAN'S HAND peels the flap of an official looking brown envelope. On it's front can be read the address of a clinic, and it is marked URGENT PERSONAL.

\section{INT STUDIO SUSAN}

SUSAN shuffles through envelope's contents. The contents surprise her. Reading the papers, Susan mumbles to herself.

SUSAN fans papers out across the tables surface as to actually prove their existence by the amount of space they take up. SUSAN shakes her head "no" over and over, begins muttering, then bangs the coffee table with her fist.

\section{INT KITCHEN AMANDA, LOWELL}

LOWELL slams baby shoe against the kitchen table coinciding with the sound SUSAN'S fist makes. AMANDA continues reading her mail, unaffected by the shoe's outburst.

\section{EXT STREET SUSAN WALKING RAPIDLY DAY}

The camera jostles itself unsteadily following Susan. She moves through streets geographically aware of her surroundings, but emotionally stranded.

Susan's face concentrates on the movements of her feet over concrete.

\section{EXT STREET CLOSE SHOT ${ }^{\circ}$ HANDS SWITCHING ENVELOPE}

Susan shifts the brown envelope between hands between and burying her empty hand in the drab interiors of her pockets.

\section{EXT STREET CLOSE SHOT SUSAN'S FEET}

SUSAN'S feet, SIDE VIEW LEVEL W/STREET. Her place, her role has become uncertain in the hurried shuffling of Susan's feet. As she walks a rumpled piece of newspaper blows by her feet, she kicks it.

\section{EXT STREET FULL SHOT SUSAN}

Susan stands out side of a shoe store. She enters the building. 
I need shoes for an infant.
CLERK
How old?

What?

SUSAN

CLERK

How old is the infant?

EXT STREET SUSAN

SUSAN walks from the shoe store and goes across the street to drug store.

INT DRUG STORE CLOSE SHOT RAZOR PACKAGE

SUSAN'S hand moves into frame and picks out an all purpose cutting tool. On the package it says the tool is great for opening everything.

EXT STREET SUSAN, FAT MAN CARRYING GRAPEFRUIT

SUSAN exits the drug store and walks into FAT MAN carrying four grapefruit in a clear plastic produce bag.

SUSAN PASSES FAT MAN. SHOT FROM BEHIND FAT MAN. Susan passes him but bumps him, he drops grapefruit bag and tosses hands up swearing at her; his lips move but no sound comes out.

TWO STREET PERFORMERS JUGGLE between themselves. A MIME walks into her.

Excuse me, sorry.

\section{MIME}

$$
\text { SUSAN }
$$

(To herself)

Now mimes are talking.

She finds herself in front of a florist shop. 


\section{INT MALL SUSAN DAY}

SUSAN stands in the middle tier of a three story galleria type mall. She appears insignificant and claustrophobic. She also drinks coffee from a paper cup.

\section{INSERT CLOSE SHOT SIGN READING 'SELF HELP'}

SUSAN stand in the self-help section of a bookstore seeking a healing remedy. A BOOKCLERK dusts off the spines of as he walks through aisle.

Can you help me?

$$
\text { SUSAN }
$$

\section{BOOKCLERK}

probably not. I'm new, and I don't now much about books.

INSERT CLOSE SHOT COFFEE CUP AND SAUCER

Cup and saucer are knocked from the counter.

INT KITCHEN AMANDA, LOWELL

Sound of breaking glass comes from kitchen. Martin no longer sits at the table with Amanda and Lowell. They look up from table off to kitchen, presumably to where Martin dropped his sandwich plate.

INT STUDIO KITCHEN SUSAN

MARTIN

(vo--monotone voice)

Don't worry, I've got it. No one walk barefoot in the kitchen.

SUSAN stands over broken glass, staring blankly away from herself, her hand is cut, bleeding

LOWELL

(vo) Are you sure you're sure about this?

EXT PLAYGROUND AMANDA, LOWELL

They walk through playground framed by playing children. 
Yea. Yes, I am.

AMANDA

EXT PLAYGROUND CHILDREN

BOY pulls GIRLS hair, taunting her.

EXT PLAYGROUND AMANDA， LOWELL

They sit on bench, watch kids playing.

AMANDA

Are you sure, I mean your wife is willing to adopt.

The idea will grow on her.

LOWELL

AMANDA

She's got to agree to this, because I can't...

LOWELL

Susan is just nervous, scared. She thinks losing the child is natures way of saying she's unfit for motherhood.

AMANDA
...because I can't go through with this if...

LOWELL

Don't worry she'll come around to accepting this whole thing.

AMANDA

..she doesn't want the baby.

EXT PLAYGROUND CHILDREN

GIRL falls begins crying. No sound comes from within her.

EXT PLAYGROUND AMANDA, LOWELL

Amanda sits tense. Watching children playing does nothing to comfort her uncertainty about undergoing the procedure and carrying Lowell's child. 
EXT PLAYGROUND CLOSE SHOT CRYING GIRL'S FACE

AMANDA

(vo) I just don't want anything to go wrong.

EXT PLAYGROUND AMANDA

She bites her nails looking straight ahead.

AMANDA
(contd.)
People could get hurt.
LOWELL
(os) People already are hurt.

INSERT CLOSE SHOT CRYING GIRL

GIRL sits in dirt crying, the sound grates against everything but the unaffected children around her.

INSERT CLOSE SHOT SUSAN'S BANDAGED HAND

SUSAN'S hand rests in her lap.

INSERT CLOSE SHOT CHILDREN PLAYING PLAYGROUND DAY

Which one is yours?

WOMAN

EXT PARK PLAYGROUND

She's not here now.
DAY

SUSAN

WOMAN

I know how it is. When mine's visiting my folks or something, I watch the other kids play. Makes me feel less lonely.

I know what you mean.

SUSAN 


\section{INT STUDIO SUSAN}

SUSAN holds a lighter to the flowers red petaled tops. She goes through several of them one at a time. Voices of laughing children overlap with the image of burning rose petals.

\section{EXT PLAYGROUND AMANDA, LOWELL}

The two of them walk away from playing children in the foreground.

\section{EXT PLAYGROUND CHILD ON SWING}

A small girl swinging. She is pushed higher and higher by another small girl behind her.

\section{INT KITCHEN LOWELL}

LOWELL sits alone with head down on table pushing a sheet of paper back and forth across the tabletop.

INT STUDIO BLANK CANVAS

SUSAN reaches in and picks up canvas.

INT STUDIO SUSAN, LOWELL

SUSAN knocks over easel with canvas, and swings it across table breaking glass bottles, strewing brushes, rags and tubes of paint everywhere.

LOWELL looks towards the crash with an amazed, stunned look on his face. The sound of breaking wood and shattering glass is heard.

SUSAN breaks canvasses smashing them against the walls and any stationary piece of furniture nearby her. She is muttering incoherently.

\section{LOWELL}

Susan, Jesus Sue calm down.

(he grabs her, tries calming her, she turns on him) Sue what the fuck, relax. Stop it. Stop! What is the matter with you?

CAMERA PANS to SUSAN'S FEET. She stomps in broken glass kicking stuff on the floor; her feet bleed. 


\section{SUSAN}

Nothing. Not a single fucking thing.

\section{LOWELL}

What is wrong with you? What's happening?

\section{SUSAN}

I already answered that. Nothing is happening, that's just it. Goddamn false starts staring at me like dead fetus, which is all I'm good for making anyway, isn't that right--dead things, dead deformed things like this fucking mess. (she slams more of the paintings around)

\section{LOWELL}

Susan stop, you're bleeding.

\section{SUSAN}

You think I feel anything? I can't feel anything. I haven't felt anything for a while. Faked all my orgasms, bet you didn't know that, well why would you. Who notices anything anymore, and tell you what that's not all you don't know; there's more but you'd never understand so I'll save myself the headache and won't bother.

Lowell is speechless. Susan screams and stomps feet on floor.

\section{SUSAN}

(cont.) You'll be asking soon, though, asking more questions than you can handle, bet your ass you'll be asking, bet your ass.

Susan storms out of studio.

CAMERA PANS across STUDIO FLOOR following Susan's bloody trail to its origins in broken remains of shattered glass and splintered wood.

CAMERA PANS up to LOWELL. He stands bewildered, runs fingers over his bottom lip, then puts a cigarette in his mouth and lights it.

INT KITCHEN LOWELL, AMANDA

Lowell sits at table. Amanda walks into frame with glass of water.

So, what about this mess? 
I don't know.

\section{LOWELL}

AMANDA

Well, you better start knowing something soon. This child belongs to you.

LOWELL

What I want to do is vanish, vaporize myself and walk through walls.

\section{AMANDA}

You can't just stop and get off whenever the urge hits you, no. You are more than physically responsible here, granted all you did was masturbate into a plastic cup, but that doesn't erase your obligations.

\section{LOWELL}

Someone else could adopt it.

\section{AMANDA}

Someone else could, but you wanted a child.

That was when I had a wife.

\section{LOWELL}

\section{AMANDA}

Is that your decision? I want to be sure not wanting it is your decision right?

\section{LOWELL}

Yes, I guess it is. Unless you want to...

AMANDA

Keep it so you can visit whenever and drop by for the good stuff while I change diapers and breast feed at four in the morning. No way. It's all or nothing. I've made up my mind--this baby belongs to anybody but me. It hasn't been a month; I'm having an abortion.

That's kind of cold.

\section{LOWELL}

\section{AMANDA}

So is the shit you've pulled to get us where we are. Sure, I'll be sad to give up the baby, but I'd be losing it anyway. I was only in this for, well for...

For the pain.

\section{LOWELL}

\section{AMANDA}

More like the feeling, Lowell, the feeling of giving birth. 
AMANDA (CONT'D)

There's a difference and you have no idea what it might be.

LOWELL

Maybe we're all masochists.

AMANDA

Maybe .

\section{EXT PARK BENCH WOMAN}

SHOT FROM BEHIND at angle so that woman's face is not exposed. A woman rocks a baby carriage; springs squeak as she rocks it. CAMERA TRACKS AROUND putting her in SIDE VIEW and her long HAIR HIDES HER FACE.

WOMAN IS SEEN from the chest up, she tosses aside her hair. LOWELL'S FACE IS EXPOSED. CAMERA TRACKS BACK SLIGHTLY bringing the carriage's top into view. HE places a hand into the carriage, seemingly covering a child. CAMERA PANS DOWN ARM to hand which rests, bloodied on the carriage handle. He moves hand up and wipes forehead leaving streaks of blood across it.

SOUND CUE

LOWELL SCREAMS, BUZZING SOUND

I am stretched on your grave $(5: 33)$ by Sinead O'Connor, plays in background.

INT TATTOO PARLOR LOWELL, TATTOO ARTIST

LOWELL writhes in pain. The TATTOO ARTIST is working on Lowell's arm. Buzzing of needle ceases. Music plays softly in background.

\section{TATTOO ARTIST}

Sit still. I hurts worse if you move around.

LOWELL

I can make it. Just keep going before I change my mind.

Sound of buzzing needle resumes

\section{TATTOO ARTIST}

Like I was saying very few people truly appreciate the aesthetic value of tattoos, much less the emotional value they have for the wearer, a symbol of his or her inner being. Besides from out of this pain, a certain 
TATTOO ARTIST (CONT'D)

amount of beauty appears, and after all that was the Surrealist project--examining the everyday poetry of emerging beauty from painful ugliness. Now, a tattoo, a good tattoo becomes a momento, a remembrance of things past so to speak. Strange the mutilation we put ourselves through just to prove we're in control of the uncontrollable.

CAMERA PANS, it swings softly over the drawings of optional tattoos covering the walls. The closer camera gets to reaching the baby shoe illustration, the louder "I am stretched..." becomes until the music consumes all other sound elements within the scene.

\section{END PAN CLOSE SHOT BABY SHOE TATTOO}

Outline illustration of two baby shoes their strings knotted together in a bow...Music continues...

CUT TO

BLACK SCREEN

THE END 


\section{Bibliography}

\section{Critical Sources:}

Barthes, Roland. Writing Degree Zero. 1968.

Baudrillard, Jean. Simulations. New York: Semiotext (e), Columbia Univ., 1983.

Bazin, Andre. What is Cinema?. Berkeley: Univ. California Press, 1967.

Bergman, Ingmar. The Magic Latern: An autobiography. New York: Viking Penguin Ltd, 1988.

Brunette, Peter and Wills, David. Screen/Play: Derrida and Film Theory. New Jersey: Princeton Univ. Press, 1989.

Coates, Paul. The Study of the Lost Reflection. London: VERSO, New Left Press, 1985.

Cocteau, Jean. Past Tense: The Cocteau Diaries, Vol. One, New York: Harcourt Brace Jovanovich, 1987.

Culler, Johnathon. The Pursuit of Signs. Ithaca: Cornell, 1981.

Dmytryk, Edward. On Filmmaking. London: Focal Press, 1986. Durgnat, Raymond. Franju. Berkeley: Univ. of California Press, 1968.

Earle, Wm. A Surrealism of the Movies. Chicago: Precedent Publishing, 1987.

Eisenstein, S.M. Nonindifferent Nature. N.Y.: Cambridge Univ. Press, 1987.

. Notes of a Film Director. N.Y.: Dover Publications, 1970.

Menthuen, ig87. PSychology of Composition. N.Y.:

Menthuen, 1987 . The Psychology of Composition. N.Y.:

Foster, Hal. Recodings: Art, Spectacle, Cultural Politics. Seattle: Bay Press, 1985.

Giles, Jane. The Cinema of Jean Genet: Un Chant d'amour. London: BFI Pub., 1991. 
Harvey, David. The Condition of Postmodernity. Cambridge, Ma.: Basil Blackwell Pub, 1989.

Insdorf, Annette. francois truffaut. N.Y.: Touchstone Books, 1989 .

Jameson, Fredric. Signatures of the Visible. N.Y.:Routledge, 1990 .

Lyotard, Jean-Francois. The Postmodern Condition: A Report on Knowledge. Minneapolis: Univ. of Minnesota, 1979, 1984 .

Milie, Tom ed. Godard on Godard. N.Y.: Viking Press, 1972. Monaco, James. The New Wave. N.Y.: Oxford Univ. Press, 1975. - Alain Resnais. N.Y.: Oxford Univ. Press,

1979 .

Murry, Edward. The Cinematic Imagination: Writers and the Motion Pictures. N.Y.: Frederick Ungar Pub. Co., 1972.

Prats, A.J. The Autonomous Image: Cinematic Narration and Humanism. Kentucky: University Press of Kentucky, 1988.

Roberts, John. Postmodernism, politics and art. Manchester and NY: Manchester Univ. Press 1990.

Rodowick, D.N. The Difficulty of Difference: Psychoanalysis, sexual difference and film theory. NY: Routledge Press, 1991.

Rose, Barbara. An Interview with Robert Rauschenberg. N.Y.: Avedon/Vintage, 1987.

Ross, Andrew ed. Universal Abandon: The Politics of Postmodernism. Minneapolis: Univ. of Minnesota, 1988.

Rothman, Wm. The "I" of the Camera. N.Y.: Cambridge Univ. Press, 1988 .

Stam Robert. Subversive Pleasure: Bakhtin, Cultural Criticism and Film. Baltimore: Johns Hopkins Press, 1989 .

Wittock, Trevor. Metaphor in Film. N.Y.: Cambridge Univ. Press, 1990.

\section{Filmscripts:}

Allen, Woody. Hannah and Her Sisters. N.Y.: vintage Publishing, 1986. 
Bergman, Ingmar. Autumn Sonata, N.Y.: Pantheon Books, 1978. - From the Life of the Marionettes. N.Y.: Pantheon Books, 1980. - Four Screenplays of Ingmar Bergman. N.Y.: Simon and Schuster, 1960.

Cocteau, Jean. Two Screenplays. N.Y.: Orion Press, 1961.

Duras, Marguerite and Resnais, Alain. Hiroshima Mon Amour, N.Y.: Grove press, 1961.

Fellini, Frederico. La Strada. New Brunswick: Rutgers Films in Print Series, Rutgers Univ. Press, 1987.

Robbe-Grillet, Alain. Last Year at Marienbad. N.Y.: Grove Press, 1962 .

Soderberg, Steven. sex, lies and videotape, N.Y.: Harper \& Row Pub., 1989.

Sontag, Susan. Duet For Cannibals. N.Y.: Farrar, Straus and Giroux, 1969. Giroux, 1974 .

- Brother Carl. N.Y.: Farrar, Straus and Truffaut, Francois. The 400 Blows. N.Y.: Grove Press, 1969. 